\title{
Peran Penyuluh Pertanian Lapangan Terhadap Tingkat Kepuasan Petani di Wilayah Kerja Balai Penyuluhan Pertanian Kecamatan Barong Tongkok
}

\author{
Midiansyah Effendi ${ }^{1^{*}}$, Firda Juita ${ }^{2}$, dan Veronika Elkana ${ }^{3}$ \\ 1,2,3 Program Studi Agribisnis, Fakultas Pertanian, \\ Universitas Mulawarman, Samarinda \\ 1 Email: emdiansyah@gmail.com \\ 2 Email: firdajuita@yahoo.com \\ *Penulis korespondensi: emdiansyah@gmail.com
}

\begin{abstract}
Farmers' satisfaction towards the role of agricultural extension workers is often contradictory, sometimes the extension workers are maximized, but it has not been able to provide satisfaction to farmers. This research aimed to determine the farmers' satisfaction level, to determine the role of extension workers and to determine the efforts made by extension workers in working area of Agricultural Extension Workers, Barong Tongkok District, West Kutai Regency. This research was conducted started on July up to September 2020. Research site was determined by purposively in Geleo Asa and Geleo Baru villages it coincide by the working area of Agricultural Extension Workers, Barong Tongkok District. Respondents determinate conducted by purposive sampling method with the number of respondents as many as 33 peoples. The role of Field Agricultural Extension Workers (FAEWs) on farmers' satisfaction level was measured using a Likert Scale. As well as knowing the role of field agricultural extension workers' (FAEWs) efforts on farmers' satisfaction level by qualitative descriptive methods. Research results showed that the farmers' satisfaction level in Working Area of BPP Barong Tongkok were in the satisfactory category with an average score 45.67 and the role of field agricultural extension workers' (FAEWs) were in the playing a role category with an average score 74.26 . The results of these efforts indicate that there are efforts to increase farmers' satisfaction, extension workers assist farmers in providing assistance in form of manure, pesticides, insecticides, superior seeds varieties and agricultural tools that are very useful for farmers.

Keywords: Agricultural Extension, Farmer, Level, Role, Satisfaction
\end{abstract}

\begin{abstract}
ABSTRAK
Kepuasan petani terhadap peran penyuluh pertanian seringkali bertolak belakang, terkadang penyuluh sudah maksimal, tetapi belum mampu memberikan kepuasan kepada petani. Tujuan dari penelitian ini untuk mengetahui tingkat kepuasan petani, mengetahui peran penyuluh dan mengetahui upaya-upaya yang dilakukan penyuluh di wilayah kerja Balai Penyuluhan Pertanian Kecamatan Barong Tongkok Kabupaten Kutai Barat. Penelitian ini dilaksakan dari bulan Juli sampai September 2020. Penentuan lokasi penelitian dilakukan secara purposive di Kampung Geleo Asa dan Geleo Baru bertepatan dengan wilayah kerja Balai Penyuluhan Pertanian Kecamatan Barong Tongkok. Penentuan responden dilakukan dengan metode purposive sampling dengan jumlah responden sebanyak 33 jiwa. Peran Penyuluh Pertanian Lapangan (PPL) terhadap tingkat kepuasan petani diukur menggunakan Skala Likert. Serta mengetahui upaya-upaya peran penyuluh pertanian lapangan (PPL) terhadap tingkat kepuasan petani dengan metode deskriptif kualitatif. Hasil penelitian menunjukkan bahwa tingkat kepuasan petani di Wilayah Kerja BPP Barong Tongkok termasuk dalam kategori memuaskan dengan skor rata-rata 45,67 dan peran Penyuluh Pertanian Lapangan (PPL) termasuk dalam kategori berperan dengan skor rata-rata 74,26 . Hasil dari upaya-upaya yang dilakukan
\end{abstract}


menunjukkan bahwa adanya upaya-upaya untuk meningkatkan kepuasan petani, penyuluh membantu petani dalam memberikan bantuan baik dalam bentuk pupuk kandang, pestisida, insektisida, bibit bervarietas unggul serta alat-alat pertanian yang sangat bermanfaat bagi petani.

Kata kunci: Kepuasan, Penyuluh Pertanian, Peran, Petani, Tingkat

\section{Pendahuluan}

Penyuluhan adalah pemberian pelayanan jasa dan informasi yang dilakukan melalui proses pendidikan non formal untuk petani dan pihak terkait yang memerlukan untuk mengembangkan kemampuan petani secara dinamis agar mampu menyelesaikan sendiri setiap permasalahan yang dihadapi dengan baik, memuaskan, menguntungkan. Mutu pemberian jasa pelayanan dapat dilihat dari segi keterpercayaan (reliability), keterjaminan (assurance), penampilan (tangiability), kepermerhatian (empaty) dan ketanggapan (responsiveness). Jasa layanan itu dilakukan melalui proses pendidikan non formal guna meningkatkan kesadaran para pelaku sistem agribisnis (sasaran) yang dapat disampaikan secara langsung maupun tidak langsung melalui media cetak atau elektronik (Mahbub, 2017).

Pembangunan pertanian membutuhkan sumber daya manusia (SDM) yang berkualitas dan tangguh. Keterkaitan penyuluh dalam membantu petani baik dalam mengelola usaha petani itu sendiri, dan juga kemampuan dalam mengelola sumber daya alam secara rasional dan efisien, terampil, cakap, berpengetahuan luas, dan mampu membaca peluang pasar, serta mampu menyesuaikan diri terhadap perubahan dunia khususnya perubahan pembangunan pertanian (Kusnadi, 2011).

Peran penyuluh pertanian dapat diukur melalui tingkat kepuasan petani dalam memperoleh pelayanan dari penyuluhnya. Apabila penyelenggaraan penyuluhan tersebut dilaksanakan secara benar, kontinyu, dan konsisten, akan mampu menunjukkan kualitas penyuluh, yang sangat diharapkan oleh petani sebagai pelanggannya. Memunculkan tingkat kepuasan bagi petani yang dibina baik langsung maupun tidak langsung, selain mampu mengetahui tingkat kepuasan yang diharapkan, juga akan dapat mengukur berdampak kinerja yang terjadi pada peningkatan kesejahteraan dan kualitas hidup petani.

Atas fenomena tersebut perlu dilakukan pengukuran tingkat kepuasan petani hubungannya dengan tingkat peran penyuluh sebagai bentuk kinerja, sudah seharusnya dilakukan di wilayah kerja penyuluhan yang menjadi medan tugasnya. Senada dengan hal tersebut sudah seharusnya dilakukan kajian, terkait hubungan peran penyuluh pertanian dengan tingkat kepuasan petani, mengingat bila belum pernah dilakukan pengukuran sebaiknya segera dilakukan, agar kinerja penyuluh yang sudah dicurahkan, benar-benar diketahui manfaatnya kepada petani (Arifin, 2015). 
Kalimantan Timur memiliki beberapa kabupaten/kota yang mengandalkan sektor pertanian. Kabupaten Kutai Barat salah satu kabupaten yang mengandalkan sektor pertanian mulai dari sektor pertanian pangan seperti padi ladang, padi sawah, dan palawija, tanaman hortikultura seperti sayuran dan buah-buahan, sektor perkebunan antara lain perkebunan sawit, perkebunan karet, perkebunan kakao dan perkebunan kopi. Kecamatan Barong Tongkok adalah salah satu kecamatan di Kabupaten Kutai Barat yang mata pencaharian masyarakatnya sebagian besar sebagai petani dengan sumber daya alam yang potensial. Barong Tongkok terdapat 21 kampung yang menjadi wilayah kerja Balai Penyuluhan Pertanian (BPP) Barong Tongkok. Terdapat 17 Penyuluh Pertanian Lapangan (PPL) yang masih aktif dengan pengalaman kerja lebih dari 5 tahun dibeberapa wilayah kerja yang dinaungi oleh BPP Barong Tongkok. Kutai Barat khususnya Barong Tongkok masih kekurangan tenaga penyuluhan sehingga satu orang tenaga penyuluh harus memegang 2-3 kampung untuk menjadi penyuluh di kampung tersebut.

Penyuluh Pertanian Lapangan (PPL) di Kecamatan Barong Tongkok mengalami beberapa kendala. PPL belum bisa melakukan penyuluhan sesuai dengan programa karena adanya kendala mengenai kegiatan lain diluar jadwal yang telah ditentukan dan disepakati, sehingga jadwal bisa berubah-ubah. Kemudian rendahnya partisipasi petani dalam penyuluhan. PPL mengalami beberapa kendala untuk mengubah pemikiran petani tentang metode terbaru dan teknologi terbaru mengenai pertanian. Kurangnya tenaga penyuluh PPL yang masih sangat dibutuhkan untuk membina beberapa kampung di Kutai Barat khususnya di wilayah kerja BPP Barong Tongkok juga menjadi salah satu kendalanya.

Belum optimalnya industri pengolahan hasil pertanian yang masih menjadi permasalahan yang dihadapi PPL. Saat ini petani hanya fokus menanam beberapa komoditi pertanian. Permasalahan lain yang dihadapi PPL juga mengenai infrastruktur yang belum memadai misalkan jauh nya jarak lahan pertanian milik petani, rusaknya jalan yang harus dilewati oleh PPL demi menjangkau petani. Belum optimalnya pemanfaatan potensi lahan pertanian karena kurangnya biaya yang dihadapi petani sehingga menjadikan petani menjadi terpaku hanya kepada lahan-lahan yang telah beberapa kali digarap. Namun ada juga petani yang setelah melakukan penanaman padi gunung, setelah pemanenan lahan tersebut ditanami tanaman tahunan seperti karet, sawit, kopi dan kakao.

Penyuluh menilai bahwa suatu layanan tertentu penting bagi petani. Oleh sebab itu kinerjanya harus baik, padahal sesuatu yang dianggap baik oleh penyuluh terkadang merupakan sesuatu yang tidak penting bagi petani, sehingga sesuatu yang diusahakan oleh penyuluh menjadi sia-sia karena tidak dapat memberikan kepuasan kepada petani. Sebaliknya persepsi yang negatif oleh penyuluh justru hal positif bagi petani. Oleh karena 
ISSN 2354-7251 (print)

itu, menjadi penyuluh untuk terus menerus berusaha mengetahui segala yang dibutuhkan petani, sehingga dapat memberikan kepuasan dengan demikian penyuluh dapat mengalokasikan sumberdaya secara tepat untuk menghasilkan kualitas yang tinggi dan mencapai kinerja yang baik (Mardikanto, 2009). Tujuan dari penelitian ini adalah:

1. Mengetahui tingkat kepuasan petani terhadap peran PPL.

2. Mengetahui peran PPL dalam meningkatkan kepuasan petani.

3. Mengetahui upaya-upaya meningkatkan peran penyuluh pertanian dalam meningkatkan kepuasan petani.

\section{$2 \quad$ Metode Penelitian}

\section{Waktu dan Lokasi}

Penelitian dilaksanakan pada bulan Mei 2020 sampai dengan Juli 2020. Tempat penelitian berlokasi di wilayah Kerja BPP Kecamatan Barong Tongkok Kabupaten Kutai Barat.

\section{Metode Pengumpulan Data}

Data yang dibutuhkan oleh peneliti meliputi data primer dan data sekunder. Data primer, yaitu data yang diperoleh peneliti melalui pengamatan langsung di lapangan dan obsevasi, hasil wawancara atau hasil dari pengisian kuisioner yang diperoleh dari petani atau dari penyuluh di Wilayah Kerja BPP Kecamatan Barong Tongkok. Data sekunder, yaitu data yang diperoleh dari literatur dan instansi terkait. Seperti data kelompok tani, data potensial wilayah, profil BPP Kecamatan Barong Tongkok, dan sumber-sumber penelitian lain yang mendukung penelitian ini.

\section{Metode Pengambilan Sampel}

Penentuan lokasi dan sampel dalam penelitian menggunakan metode purposive sampling. Terdapat 2 desa dari 21 Desa binaan BPP Kecamatan Barong Tongkok yang masuk dalam kategori pemula dan sudah berkembang yaitu Desa Geleo Asa dengan 2 Kelompok Tani dan Geleo Baru dengan 2 kelompok tani. Metode purposive sampling adalah teknik penentuan sampel secara sengaja dengan memenuhi kriteria tertentu. Kriteria dalam penelitian ini yaitu petani yang tergabung dalam kelompok tani dan aktif mengikuti kegiatan penyuluhan (teknis budidaya tanaman, pengembangan kelompok dan penyusunan RDK/RDKK). Total jumlah petani pada 4 kelompok tani sebanyak 80 petani, petani yang memenuhi kriteria di atas hanya sebanyak 33 orang berdasarkan data kehadiran dalam 1 tahun, Sehingga sampel dalam penelitian ini berjumlah 33 responden.

\section{Metode Analisis Data}

Metode yang digunakan dalam penelitian ini dengan menggunakan pendekatan Kualitatif yang bersifat Deskriptif. Adapun alat ukur data pada penelitian ini menggunakan skala likert. Pengukuran indikator-indikator yang telah dijabarkan dalam bentuk kuisioner. 
Setiap pertanyaan yang diberikan skor sesuai dengan pilihan responden. Metode yang digunakan ialah Skoring yang artinya atribut yang tersedia diberikan skor yang berbeda. Pilihan A diberikan skor 4, pilihan B diberikan skor 3, pilihan C diberikan skor 2, dan pilihan $\mathrm{D}$ diberikan skor 1. Tahap analisis data dilakukan dengan menggunakan metode analisis Arithmetic Mean (Anonim, 2017) yang digunakan untuk melihat bagaimana peran PPL terhadap tingkat kepuasan petani di wilayah kerja BPP Kecamatan Barong Tongkok.

$$
\mathrm{AM}=\frac{\mathrm{X} . \mathrm{K}}{\mathrm{N} . \mathrm{n}}=\frac{\text { Jumlah Skor Jawaban }}{\text { Jumlah Responden X Jumlah Atribut }}
$$

Keterangan: $\quad X=$ Skor masing-masing bobot

$$
\begin{aligned}
& \mathrm{K}=\text { Jumlah responden yang menjawab tiap butir pertanyaan } \\
& \mathrm{N}=\text { Jumlah responden } \\
& \mathrm{n}=\text { Jumlah butir }
\end{aligned}
$$

Hasil perhitungan Arithmetic Mean dibuat dalam kategori dengan menggunakan rumus:

$$
\text { Interval Kelas }=\frac{\text { Skor Tertinggi }- \text { Skor Terendah }}{\text { Jumlah kriteria Jawaban }}
$$

Dimana skor terendah adalah 1 dan skor tertinggi adalah:

$$
\text { Interval Kelas }=\frac{4-1}{4}=0,75
$$

Tabel 1. Interval kelas kriteria Peran Penyuluh Pertanian (PPL) dan tingkat kepuasan petani

\begin{tabular}{ccc}
\hline & Kriteria Penilaian PPL & Kriteria Penilaian Kepuasan \\
\cline { 2 - 3 } Rata-Rata & Peran PPL & Tingkat Kepuasan Petani \\
\hline 1,0 & Tidak Berperan & Tidak Memuaskan \\
2,0 & Cukup Berperan & Cukup Memuaskan \\
3,0 & Berperan & Memuaskan \\
4,0 & Sangat Berperan & Sangat Memuaskan \\
\hline
\end{tabular}

Sumber: data (diolah), 2020

\section{Hasil dan Pembahasan}

\section{Kepuasan Petani}

Diketahui bahwa hasil keseluruhan indikator tingkat kepuasan petani di Kecamatan Barong Tongkok yaitu di Kampung Geleo Asa dan Geleo Baru masuk dalam kategori memuaskan. Untuk lebih jelasnya dapat dilihat pada Tabel 2.

Tabel 2. Tingkat kepuasan petani

\begin{tabular}{clccc}
\hline No. & Kepuasan Petani & Total Skor & Skor Rata-Rata & Kategori \\
\hline 1 & Tangible & 263 & 9,79 & Memuaskan \\
2 & Reliability & 256 & 8,48 & Memuaskan \\
3 & Alacrity & 257 & 8,48 & Memuaskan \\
4 & Assurance & 263 & 9,78 & Memuaskan \\
5 & Empathy & 261 & 9,13 & Memuaskan \\
\hline & Jumlah & 1.300 & 45,67 & Memuaskan \\
\hline
\end{tabular}

Sumber: Data primer 2020 (diolah) 


\section{Peran Penyuluh Pertanian PPL}

Diketahui bahwa hasil keseluruhan indikator peran PPL di Kecamatan Barong Tongkok di Desa Geleo Asa dan Geleo Baru masuk dalam kategori berperan. Untuk lebih jelasnya dapat dilihat pada Tabel 3.

Tabel 3. Peran PPL

\begin{tabular}{llccl}
\hline No. & Peran PPL & Total Skor & Skor Rata-rata & Kategori \\
\hline 1 & Penasehat & 346 & 11,41 & Berperan \\
2 & Teknisi & 635 & 21,55 & Berperan \\
3 & Penghubung & 223 & 7,35 & Berperan \\
4 & Organisator & 549 & 18,11 & Berperan \\
5 & Agen Perubahan & 448 & 15,84 & Berperan \\
\hline
\end{tabular}

Sumber: Data primer 2020 (diolah)

\section{Tingkat Kepuasan Petani Terhadap Peran Penyuluh Pertanian Lapangan (PPL)}

Tingkat kepuasan petani terhadap suatu pelayanan memiliki faktor-faktor tertentu yang mempengaruhinya. Kualitas pelayanan yang diberikan PPL dapat mempengaruhi tingkat kepuasan petani. Tingkat kepuasan petani dapat ditinjau dari beberapa indikator yaitu penampilan (tangible), keterpercayaan (reliability), ketanggapan (responsiveness), jaminan (assurance) dan kepemerhatian (empathy) (Syahrani, 2016). Hasil penelitian secara keseluruhan indikator tingkat kepuasan petani terhadap peran PPL masuk dalam kategori memuaskan dengan skor rata-rata keseluruhan indikator 45,67. Hal ini menunjukkan bahwa tingkat kepuasan petani terhadap PPL rata-rata sudah memuaskan karena petani berpendapat bahwa penyuluh sudah menjalankan tugasnya dengan baik seperti rutin mengadakan pertemuan dan langsung meninjau keadaan petani di lapangan, membantu memberi solusi untuk permasalahan petani. Kemampuan penyuluh dalam melaksanakan tugas dengan baik dapat memberikan kepuasan kepada petani (Darmawati, 2019).

Penyampaian materi oleh penyuluh mudah dipahami oleh petani. Materi yang diberikan penyuluh selalu disesuaikan dengan kebutuhan petani. Penyuluh merupakan pihak penghubung yang dapat menyampaikan kebutuhan dan keluhan petani kepada instansi pemerintah terkait. Penyuluh berfungsi sebagai penghubung antara petani dengan pihak pemerintah atau instansi lainnya (Listiawati, 2010). Berdasarkan data yang dijabarkan pada hasil penelitian, berikut ini pembahasan dari setiap indikator kepuasan petani terhadap peran PPL.

\section{Penampilan (tangible)}

Kepuasan petani pada indikator penampilan bertujuan untuk mengetahui tingkat kepuasan petani terhadap peran PPL. Berdasarkan hasil penelitian bahwa kepuasan petani yang dipengaruhi oleh indikator penampilan masuk dalam kategori memuaskan. Alat peraga yang biasa digunakan penyuluh adalah spanduk, brosur, dan alat pengeras suara, sedangkan penggunaan proyektor hanya digunakan jika kegiatan dilakukan di 
kantor BPP. Pelayanan yang diberikan penyuluh sudah sangat baik. Penyuluh dapat menjelaskan dengan sangat baik dan mudah dimengerti oleh petani. Seorang penyuluh harus terbiasa dengan sistem pertanian dan perlu berempati dengan kehidupan dan keputusan petani, baik secara teoritis maupun praktis. Penyuluh harus mampu memberikan praktis metode dan metode budidaya tanaman, sehingga petani dapat menemukan dan menggunakan peralatan dan fasilitas produksi pertanian yang sesuai (Putra, 2016). Menurut petani adanya pertemuan dan penyuluhan yang dilaksanakan di balai pertemuan masih jarang dilakukan, rata-rata pertemuan dan penyuluhan yang dilaksanakan dibalai pertemuan dilakukan sebanyak 1-4 kali dalam sebulan karena beberapa kampung dengan jarak yang ditempuh ke kantor BPP cukup jauh, sehingga penyuluh biasanya lebih banyak melakukan pertemuan dan penyuluhan dengan petani langsung di lapangan agar mempermudah komunikasi antar penyuluh dengan petani.

2. Keterpercayaan (Reliability)

Keterpercayaan dapat diartikan pemberian informasi baru dari penyuluh pertanian ke setiap anggota kelompok tani, keterpercayaan yang dimaksud adalah keterpercayaan dalam memberikan pelayanan (Basri, 2017). Kepuasan petani pada indikator keterpercayaan bertujuan untuk mempengaruhi tingkat kepuasan petani terhadap peran penyuluh pertanian yang diberikan penyuluh dalam memberikan kepercayaan kepada petani dan kesigapan dalam memenuhi kebutuhan petani. Berdasarkan hasil penelitian yang dilakukan menyatakan bahwa kepuasan petani yang dipengaruhi oleh indikator keterpercayaan masuk dalam kategori memuaskan. Penyuluh sering mengunjungi petani di lapangan untuk meninjau langsung keadaan petani dan saling berkomunikasi untuk bertukar pikiran, petani menceritakan permasalahan yang sedang dihadapi dan penyuluh langsung merespon keluhan yang telah diceritakan oleh petani, dalam sebulan biasanya penyuluh mengunjungi petani sebanyak 1-2 kali bahkan lebih, khusus untuk petani yang mempunyai masalah dengan kondisi pertaniannya.

Penyuluh selalu hadir tepat waktu jika ada pertemuan penyuluhan yang telah direncanakan. Petani lebih nyaman karena tidak harus menunggu lama untuk memulai kegiatan penyuluhan. Penyuluh jarang membatalkan kegiatan penyuluhan yang sudah direncanakan, biasanya penyuluh membatalkan kegiatan tersebut dikarenakan faktor cuaca yang tidak mendukung pada saat pertemuan atau jika ada rapat dadakan di BPP. Indikator keterpercayaan masuk dalam kategori memuaskan karena menurut petani materi yang penyuluh berikan sudah sesuai dengan kebutuhan petani, ketepatan waktu dalam menghadiri penyuluhan juga selalu dijaga oleh penyuluh serta penyuluh dinilai adil dalam memberikan respon yang baik kepada setiap petani atau kelompok tani. 
ISSN 2354-7251 (print)

\section{Ketanggapan (Responsiveness)}

Kepuasan petani pada indikator ketanggapan bertujuan untuk mengetahui tingkat kepuasan petani terhadap peran penyuluh pertanian lapangan (PPL) dalam membantu memberikan solusi permasalahan dan memberikan pelayanan yang sesuai kebutuhan petani (Basri, 2017). Berdasarkan hasil penelitian yang dilakukan menyatakan bahwa kepuasan petani yang dipengaruhi oleh indikator ketanggapan masuk dalam kategori memuaskan. Petani menyampaikan sesuatu pada saat petani bertanya tentang permasalahan mereka, penyuluh selalu menjawab dengan jawaban yang penyuluh kuasai terkait masalah tersebut, penyuluh akan berusaha mencari jawaban yang sesuai dan akan menyampaikannya dikeesokan harinya atau menghubungi petani langsung melalui via telepon.

Pada saat melakukan komunikasi penyuluh memberikan saran dan masukan kepada petani terkait dengan kegiatan usahatani seperti penyuluh memberikan saran tentang penggunaan pestisida yang lebih ampuh dalam membasmi hama dan penyakit tanaman. Ketanggapan penyuluh juga dinilai baik oleh petani, penyuluh dianggap cepat merespon jika ada masalah yang sedang dihadapi oleh petani dengan bertemu langsung dengan petani. Indikator ketanggapan masuk dalam kategori memuaskan karena penyuluh selalu dinilai cepat dan tanggap dalam menghadapi masalah petani. Kemudian penyuluh selalu cepat tanggap dalam menangani permasalahan petani dan penyuluh selalu siap dalam membantu petani mencari solusi terbaik terkait dengan usahatani mereka.

4. Jaminan (Assurance)

Jaminan yaitu mencakup pengetahuan, kemampuan, kesopanan dan sifat dapat dipercaya yang dimiliki para staff, bebas dan bahaya resiko atau keragu-raguan (Fikri et al., 2016). Kepuasan petani pada indikator jaminan bertujuan untuk mengetahui tingkat kepuasan petani terhadap peran PPL dalam memberikan kepercayaan dan keyakinan kepada petani untuk diandalkan. Berdasarkan hasil penelitian yang dilakukan menyatakan kepuasan petani yang dipengaruhi oleh indikator jaminan masuk dalam indikator memuaskan. Penyuluh selalu menyampaikan materi dengan jelas, menyampaikan materi dengan menggunakan bahasa daerah dan bahasa Indonesia, tergantung pada keluarga tani yang ditemui, karena masih ada sebagian petani dan keluarganya menggunakan bahasa daerah. Dengan penggunaan bahasa daerah diharapkan materi penyuluhan yang disampaikan akan lebih mudah dipahami. Materi yang disampaikan oleh penyuluh disesuaikan dengan kebutuhan petani sehingga materi yang sudah disampaikan dapat langsung dimengerti dan dapat diterapkan oleh petani pada usahataninya. Penyuluh juga dapat menciptakan suasana yang kondusif pada saat penyuluhan sehingga membuat petani merasa nyaman pada saat mengikuti kegiatan tersebut. 
Penyuluh belum bisa membantu petani dalam merealisasikan semua bantuan yang dibutuhkan petani karena terkadang bantuan yang dibutuhkan petani di luar kemampuan seorang penyuluh seperti bantuan pupuk, bibit, obat-obatan, dan alat mesin pertanian, tetapi penyuluh selalu berusaha menyampaikan keluhan kebutuhan petani kepada pihak-pihak dan instansi terkait. Indikator jaminan masuk dalam kategori memuaskan karena penyuluh mampu menyelsaikan masalah yang dihadapi secara tuntas dan penyuluh memberikan informasi yang jelas dan mudah dimengerti oleh petani dan penyuluh dalam meyampaikan informasi selalu bersikap ramah serta penyuluh memiliki pengetahuan dan kecakapan dalam menyelsaikan masalah yang dihadapi oleh petani.

\section{Kepemerhatian (Empathy)}

Kepemerhatian sangat penting dalam customer service dan pelanggan (Sirclo, 2018). Kepuasan petani pada indikator kepemerhatian bertujuan untuk mengetahui tingkat kepuasan petani terhadap peran PPL dalam memahami keinginan dan kebutuhan seorang petani dan memberikan perhatian kepada petani. Berdasarkan hasil penelitian yang dilakukan menyatakan bahwa kepuasan petani yang dipengaruhi oleh indikator kepemerhatian memuaskan. Perhatian yang diberikan penyuluh dinilai sudah memuaskan karena penyuluh aktif dalam mengunjungi petani baik di lapangan maupun berkunjung ke kediaman petani untuk bersilaturahmi dan mengajak petani berdiskusi terkait usahatani, serta mau mendengarkan permasalahan yang sedang dihadapi oleh petani.

Penyuluh juga dinilai mampu untuk memahami maksud dari keinginan seorang petani, penyuluh tidak hanya mendengarkan keluhan petani namun petani terkadang diajak untuk mendengarkan dan berdiskusi tentang keadaan sosial yang sedang dihadapi petani sehingga penyuluh dapat memahami secara jelas bagaimana keadaan sosial petani binaannya. Penyuluh melakukan kunjungan ke lapangan untuk menyebarkan materi penyuluhan yang sesuai dengan kebutuhan petani. Sebelum melakukan kunjungan dan penyebaran materi penyuluh akan melakukan penjadwalan kunjungan kerja di tiap kelompk tani.

\section{Peran Penyuluh Pertanian Lapangan (PPL) di Kecamatan Barong Tongkok}

Peran PPL dapat mempengaruhi tingkat kepuasan seorang petani (Mulyana, 2012). Tugas penyuluh adalah berusaha terus menerus dalam, mengetahui faktor yang dapat memberikan kepusan kepada petani,sehingga penyuluh dapat mengalokasikan sumberdaya secara tepat dan berhasil guna untuk kinerja yang optimal (Subagio, 2010). Peran PPL di Kecamatan Barong Tongkok dapat ditinjau dari beberapa indikator yaitu penasehat, teknisi, penghubung, organisator dan agen perubahan. Hasil penelitian secara keseluruhan indikator peran PPL masuk dalam kategori berperan dengan skor rata-rata keseluruhan indikator tingkat PPL sebesar 74,26. Hal ini menunjukkan bahwa peran PPL 
yang dilaksanakan di lokasi penelitian sudah termasuk kategori berperan. Penyuluh dapat dipercaya dalam menjembatani petani dengan instansi pemerintah. Perhatian yang diberikan oleh penyuluh baik dan adil bagi semua petani, baik yang tergabung dalam kelompok tani maupun yang tidak tergabung dalam kelompok tani, penyuluh juga membantu membina petani dalam memahami perencanaan kelompok, seperti membuat programa penyuluhan pertanian, dalam hal Rencana Definitif Kebutuhan Kelompok (RDKK) sehingga akan memudahkan petani dalam menyusunnya. Berdasarkan data yang dijabarkan pada hasil penelitian tiap indikator peran PPL di Kecamatan Barong Tongkok yaitu penasehat, teknisi, penghubung, organisator, dan agen perubahan sebagai berikut:

\section{Penasehat}

Peran PPL pada indikator penasehat bertujuan untuk mengukur peran PPL dalam mengenal kebutuhan para petani, menyusun dan prioritas peran serta mengembangkan program-program dengan kebutuhan dan aspirasi petani (Mulyono, 2011). Peran PPL yang dipengaruhi oleh indikator penasehat masuk dalam kategori berperan. Penyuluh sering melakukan praktik atau demonstrasi tentang suatu cara atau metode budidaya tanaman pertanian yang sesuai dengan komoditi yang diusahakan oleh petani. Penyuluh dapat memberikan saran kepada petani tentang sumber kredit yang digunakan untuk pengembangan pertanian dan memenuhi kebutuhan petani dari instansi/stakeholder terkait. Penyuluh sering melakukan memberikan materi dan informasi kepada petani yang dilakukan 2-3 kali dalam sebulan melalui kegiatan penyuluhan secara langsung maupun menggunakan brosur atau pamplet. Materi yang diberikan penyuluh biasanya terkait inovasi terbaru serta materi untuk solusi pemecahan masalah serta saran dalam kegiatan usahatani.

Kaitan indikator empati masuk dalam kategori memuaskan karena penyuluh harus mampu menempatkan diri sebagai bagian dari kehidupan petani dengan memahami segala permasalahan yang dihadapi maupun bantuan solusi terbaik yang terjadi, agar petani mampu mengatasi segala persoalan, baik terkait usahatani maupun sosial. dengan melakukan kunjungan langsung ke lapangan dan memberikan materi penyuluhan yang sesuai dengan kebutuhan petani. Sebelum melakukan kunjungan dan penyebaran materi penyuluh akan melakukan penjadwalan kunjungan kerja di tiap kelompk tani melalui ketua kelompok tani, sehingga petani dapat mengikuti semua kegiatan dengan baik, agar peran penyuluh sebagai penasehat berjalan optimal.

\section{Teknisi}

Peran PPL pada indikator teknisi untuk mengukur peran PPL dalam mengenal kebutuhan para petani, menyusun dan prioritas peran serta pengetahuan teknis kepada petani serta memberikan manfaat kepada petani. Berdasarkan hasil penelitian yang 
dilakukan menyatakan bahwa peran penyuluh pertanian lapangan PPL menurut petani yang dipengaruhi oleh indikator teknisi masuk dalam kategori berperan. Pengetahuan dan keterampilan penyuluh secara teknis cukup baik. Penyuluh mampu secara teknis berperan dalam ilmu pengetahuan dan keterampilan teknis yang baik. Penyuluh mampu memberikan pelayanan jasa konsultasi yang diminta oleh petani sesuai dengan kebutuhan petani bagi usahatani.

Penyuluh biasanya meninjau kembali hasil program dan kegiatan yang telah penyuluh berikan dan jika hasil program yang diberikan penyuluh tidak sesuai harapan, penyuluh akan menyesuaikan kembali program tersebut dengan keadaan di lapangan dan memberikan penjelasan yang lebih jelas dan mudah dipahami tentang program tersebut kepada petani. Indikator peran penyuluh teknisi masuk dalam kategori berperan karena dalam penyusunan program pertanian. Penyuluh terlibat secara langsung dalam membina petani. Dalam hal teknisi penyuluh pertanian diharapkan mampu dalam memberikan suatu inovasi dan metode baru yang berujung pada peningkatan kualitas hasil yang diharapkan, hal ini disebabkan dari cara penyuluh menyampaikan dan memberikan demonstrasi agar lebih mudah dipahami dan diterapkan anggota kelompok karena umumnya petani akan lebih menyukai adanya praktik dibandingkan teori yang disampaikan penyuluh (Saihani \& Jamil, 2017).

\section{Penghubung}

Peran penyuluh pertanian pada indikator penghubung bertujuan untuk mengukur bentuk tugas dan tanggung jawab yang dilakukan oleh penyuluh guna memenuhi harapan dan kepuasan petani dalam memberikan pelayanan informasi, ketepatan materi serta metode penyuluhan (Faqih, 2014). Berdasarkan hasil penelitian yang dilakukan menyatakan bahwa peran PPL yang dipengaruhi indikator penghubung masuk dalam kategori cukup berperan. Menurut petani, penyuluh selalu melakukan kunjungan langsung ke lapangan dan memberikan beberapa pelatihan dalam sistem kerja penyuluhan. Dalam hal ini penyuluh dinilai petani lebih efektif karena petani dapat langsung menyampaikan permasalahan mereka sehingga penyuluh juga dapat langsung menanggapi keluhan dari petani tersebut, selain itu penyuluh juga lebih mengetahui kondisi yang sebenarnya terjadi di lapangan.

Menurut petani pada masa pandemi ini petani masih bisa mendapatkan informasi terkini dari penyuluh mengenai pertanian terkini, masalah pertanian dan solusi pertanian dengan teknologi penyuluhan Rompi (Radio zoom dan Aplikasi) yang telah diresmikan penggunaannya oleh Kepala Dinas Pertanian Kutai Barat Bapak Petrus S.Hut,.M.Si. (Sekretariat Kabupaten Kutai Barat, 2020). Menurut petani dengan adanya penyuluhan Rompi, petani lebih mudah mendapatkan informasi dari penyuluh agar lebih optimal di lapangan dan petani juga lebih cepat mendapat informasi. Penyuluhan perdana yang 
ISSN 2354-7251 (print)

dilasanakan pada tanggal 9 September 2020 lalu dengan tema "Berdaya Guna dan Produktif di Masa Pandemi Covid 19". Pertemuan melalui zoom meeting membuat kelompok tani sangat antusias, karena tidak perlu berkumpul. Cukup di lokasi yang memiliki jaringan internet stabil. Selain pelatihan dan penyuluhan melalui zoom meeting, Kepala Dinas Pertanian melakukan penyuluhan melalui radio secara oneway dan interaktif dimana penyiaran melalui radio Dinas Pertanian bekerjasama dengan Dikominfo menyiarkan siaran interaktif dan RRI Sendawar menyiarkan siaran oneway.

4. Organisator

Peran PPL pada indikator organisator bertujuan untuk mengukur sejauh mana cara berkomunikasi dan hubungan penyuluh dengan petani binaannya dan memberikan informasi kepada petani sesuai dengan kebutuhan petani. Penyuluh pertanian juga melakukan kegiatan sosialisasi bulanan dengan setiap kelompok tani untuk membantu petani mengembangkan kelompok tani dan usaha mereka sendiri (Marbun et al., 2019). Berdasarkan hasil penelitian menyatakan bahwa peran PPL yang dipengaruhi indikator organisator masuk dalam kategori berperan. Menurut petani penyuluh memberikan materi yang membuka wawasan petani tentang suatu lembaga-lembaga dan sosial dan bergabung dalam kelompok tani yang memiliki peran penting dalam pengembangan usahatani. Menurut petani penyuluh mengajak petani untuk bersama-sama membentuk dan mengembangkan kelompok tani.

Penyuluh juga melakukan bimbingan teknis yang dilaksanakan demi mendukung program Upsus Pajale meliputi cara mengoperasikan Hand Tractor, pembuatan semaian (Dapog) dan pengenalan 3 sistem tanam (Atabela dengan paralon, Tapin dengan Jarwo 4:1, dan Transplanter Jarwo 2:1. Bimbingan teknis yang dilaksakan yaitu Penggunaan Mekanisme Transplanter di Sawah Ketilamp Kampung Geleo Baru dan Geleo Asa Kecamatan Barong Tongkok Kabupaten Kutai Barat.

\section{Agen Perubahan}

Peran PPL pada indikator agen perubahan bertujuan untuk mengetahui sejauh mana perubahan yang dirasakan oleh petani terhadap kinerja PPL dalam melakukan tugasnya. Penyuluh mengembangkan kegiatan dalam berbagai aspek, antara lain pengembangan sumberdaya manusia kelompok tani dan optimalisasi sumberdaya alam yang dapat dimanfaatkan untuk mensejahterakan dan memberi manfaat bagi anggota kelompok tani. Sebagai pengelola petani, penyuluh pertanian menyadari bahwa pengembangan sumberdaya manusia sangat penting, sehingga perlu dibentuk kelompok tani untuk memajukan pembangunan (Lini et al., 2018).

Berdasarkan hasil penelitian yang dilakukan menyatakan bahwa peran PPL menurut petani yang dipengaruhi oleh indikator agen perubahan masuk dalam kategori berperan. Petani menyatakan penyuluh membantu petani dalam memberikan pendapat 
yang sehat dan membantu membuat keputusan yang baik dengan cara berkomunikasi dan memberikan informasi yang sesuai dengan kebutuhan petani. Petani menyatakan penyuluh membantu petani untuk mengambil keputusan yang dinilai dapat menguntungkan petani dan juga bagi penyuluh karena sudah menjalankan tanggung jawab. Tugas agen penyuluh adalah menghilangkan hambatan ini dengan memberikan informasi dan wawasan tentang masalah yang dihadapi saat ini. Penyuluh dapat membantu dengan memberikan informasi teknis yang relevan tentang masalah yang dibutuhkan petani dan menunjukkan bagaimana menyelesaikannya. Selama penyuluh tidak dapat memberikan informasi yang dibutuhkan petani, maka kegiatan penyuluhan tidak akan dapat berfungsi (Setiawan, 2005). Menurut petani dalam membantu memenuhi kebutuhan petani, penyuluh terkadang melakukan pendataan yang biasa dilakukan sebulan sekali, pendataan ini dilakukan guna untuk mengetahui kebutuhan apa saja yang diperlukan petani, berkaitan dengan kebutuhan pupuk, bibit, obat-obatan dan alat-alat pertanian untuk menunjang kegiatan usahatani.

\section{Kesimpulan}

Berdasarkan hasil penelitian mengenai peran penyuluh pertanian terhadap tingkat kepuasan petani di Wilayah Kerja BPP Kecamatan Barong Tongkok Kabupaten Kutai Barat, dapat ditarik kesimpulan bahwa:

1. Tingkat kepuasan petani di Wilayah Kerja BPP Barong Tongkok pada indikator kepenampilan, keterpercayaan, ketanggapan, keterjaminan, kepemerhatian termasuk dalam kategori memuaskan dengan skor rata-rata 45,67 dan peran Penyuluh Pertanian Lapangan (PPL) termasuk dalam kategori berperan dengan skor rata-rata 74,26 .

2. Peran penyuluh pertanian lapangan PPL di Wilayah Kerja BPP Barong Tongkok pada indikator penyuluh sebagai penasehat, teknisi, penghubung, organisator, agen perubahan termasuk dalam kategori berperan. Penyuluh dapat dipercaya dalam menjembatani petani dengan pihak pemerintah, perhatian yang diberikan penyuluh sudah sangat baik dan adil, serta penyuluh membantu petani dalam menyusun program-program yang penyuluh berikan.

3. Upaya yang dilakukan penyuluh untuk meningkatkan kepuasan petani mencakup beberapa hal seperti memberikan penyuluhan mengenai teknologi baru yang sangat dibutuhkan petani pada saat itu; penyuluh membantu petani dalam memberikan bantuan baik dalam bentuk, pupuk, bibit, obat-obatan dan alat-alat pertanian yang menunjang kebutuhan petani; penyuluh juga mengikutsertakan petani dalam menyusun program-program yang nantinya bisa menjadi acuan untuk meningkatkan kinerja penyuluh dan meningkatkan usahatani itu sendiri. 


\section{Daftar Pustaka}

Arifin, M. (2015). Analisis Tingkat Kepuasan Petani Terhadap Kinerja Pelayanan Penyuluh Pertanian (Studi Kasus di BP3K Kalibawang, Kab. Kulon Progo, D.I. Yogyakarta). Agrica Ekstensia, 9(1), 40-49.

Basri. (2017). Kualitas Pelayanan Penyuluhan dalam Rangka Peningkatan Ketahanan Pangan di Kecamatan Sambaliung Kabupaten Berau. Universitas Terbuka, Jakarta.

Darmawati, D. (2019). Kepuasan Petani Terhadap Pelayanan Penyuluh Pertanian Dalam Aktivitas Penyuluhan Pertanian di Kabupaten Banyuasin (Kasus Kelompok Tani di Kecamatan Makarti Jaya). Palembang: Universitas Muhammadiyah Palembang.

Faqih, A. (2014). Peranan Penyuluh Pertanian Lapangan (PPL) Dalam Kegiatan Pemberdayaan Kelompok Terhadap Kinerja Kelompok Tani. Jurnal Agrijati, 26(1), $41-60$.

Fikri, S., Wiyani, W., \& Suwandaru, A. (2016). Pengaruh Kualitas Pelayanan Terhadap Kepuasan dan Loyalitas Mahasiswa. Jurnal Bisnis Dan Manajemen, 3(1), 120-134.

Kusnadi, D. (2011). Modul Dasar-Dasar Penyuluhan Pertanian. Sekolah Tinggi Penyuluhan Pertanian Bogor. Retrieved from http://eprints.stiperdharmawacana.ac.id/79/1/Modul Dasar Penyuluhan \%28DK\%29.pdf.

Lini, L., Hamzah, A., \& Abdullah, S. (2018). Peranan Penyuluh Pertanian Dalam Pengembangan Kelompok Tani di Kelurahan Benua Nirae Kecamatan Abeli Kota Kendari. Jurnal Ilmiah Membangun Desa Dan Pertanian, 3(5), 128-132. https://doi.org/10.33772/jimdp.v3i5.7978

Listiawati, I. (2010). Analisis Tingkat Kepuasan Petani Terhadap Kinerja Penyuluh Lapang di BP3K Wilayah Ciawi Kabupaten Bogor. Bogor (ID): Institut Pertanian Bogor.

Mahbub, M. (2017). Bab 2 Landasan Teori. Kepuasan Konsumen. Retrieved from http://repo.darmajaya.ac.id/302/3/BAB II.pdf

Marbun, D. N. V.D., Satmoko, S., \& Gayatri, S. (2019). Peran Penyuluh Pertanian dalam Pengembangan Kelompok Tani Tanaman Hortikultura di Kecamatan Siborongborong, Kabupaten Tapanuli. Jurnal Ekonomi Pertanian Dan Agribisnis, 3(3), 537-546. https://doi.org/10.21776/ub.jepa.2019.003.03.9

Mardikanto, T. (2009). Sistem Penyuluhan Pertanian. Surakarta: Universitas Sebelas Maret.

Mulyana. (2012). Peran Penyuluh Pertanian Dalam Pengembangan Kelompok Tani. Bandung: Remaja Rosdakarya.

Mulyono, M. (2011). Pola Pengembangan Penyuluhan Pertanian Berorientasi Agribinis Pada Era Otonomi Daerah. Jakarta: Yasaguna.

Putra, S., BM. (2016). Peran Penyuluh Pertanian Dalam Pengembangan Kelompok Tani Padi Sawah di Desa Rambah Baru Kecamatan Rambah Samo Kabupaten Rokan Hulu. Universitas Pasir Pengaraian, Rokan Hulu. 
Saihani, A., \& Jamil, S. N. A. (2017). Peranan Penyuluh Pertanian Dalam Pengembangan Kelompok Tani di Desa Sungai Binuang Kecamatan Haur Gading Kabupaten Hulu Sungai Utara. Rawa Sains: Jurnal Sains Stiper Amuntai, 7(1), 8-21. https://doi.org/10.36589/rs.v7i1.68

Sekretariat Kabupaten Kutai Barat. (2020). Teknologi Rompi Promosikan Pertanian Kubar. Retrieved September 14, 2020, from http://setda.kutaibaratkab.go.id/bacaberita-697-teknologi-rompi-promosikan-pertanian-kubar.html

Setiawan, I. G. (2005). Masalah-Masalah Penyuluhan Pertanian. Jurnal Penyuluhan, 1(1), 57-61.

Sirclo. (2018). Belajar Empati Untuk Meningkatkan Kepuasan Konsumen Bisnis Online. Retrieved October 23, 2018, from Sirclo website: https://sirclo.com/belajar-empatiuntuk-meningkatkan-kepuasan-konsumen-bisnis-online/

Subagio, D. B. (2010). Tingkat Kepuasan Petani Terhadap Kinerja Pelayanan Penyuluh Pertanian di Desa Situ Udik Kecamatan Cibungbulang Kabupaten Bogor Jawa Barat. In Institut Pertanian Bogor.

Syahrani, I. (2016). Kinerja Pelayanan Penyuluh Pertanian Di Balai Penyuluh Pertanian, Perikanan Dan Kabupaten Pinrang Ida Syahrani Program Studi Administrasi Negara. Universitas Hasanuddin, Makassar. 